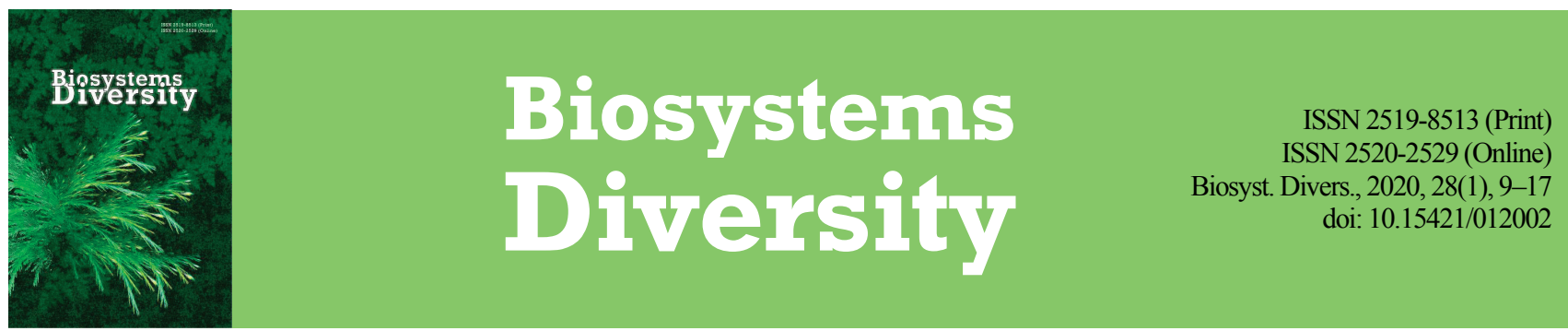

\title{
Bacterial synthesis of nanoparticles: A green approach
}

\author{
S. I. Tsekhmistrenko*, V. S. Bityutskyy*, O. S. Tsekhmistrenko*, \\ L. P. Horalskyi**, N. O. Tymoshok***, M. Y. Spivak*** \\ *Bila Tserkva National Agrarian University, Bila Tserkva, Ukraine \\ **Zhytomyr National Agroecological University, Zhytomyr, Ukraine \\ ***D. K. Zabolotny Institute of Microbiology and Virology of the National Academy of Sciences of Ukraine, Kyiv, Ukraine
}

Article info

Received 27.01.2020

Received in revised form 01.03 .2020

Accepted 02.03 .2020

Bila Tserkva National Agrarian University, Soborna Sq., 8/1, Bila Tserkva, 09117, Ukraine. $\mathrm{Tel} \cdot+38-068-034-48-48$ E-mail: svetlana. tsehmistrenko@gmail.com

Zhytomyr National Agroecological University Stary Boulevard, 7 Zhytomyr, 10002, Ukraine.

D. K. Zabolotny Institute of Microbiology and Virology of the National Academy of Sciences of Ukraine, Kyiv, Ukraine.

\section{Introduction}

The current stage of science development over the last 20 years has been characterized by comprehensive miniaturization of technological processes in chemistry, biology, medicine and agriculture, which contributes to the formation of a fundamentally new direction as nanotechnology. The term "nano" is derived from the Greek word "nanos" what means dwarf and denotes measurements of one billionth of a meter $\left(10^{-9}\right)(\mathrm{Na}-$ rayanan \& Sakthivel, 2010; Thakkar et al., 2010). The nanoparticle is a particle of a substance of arbitrary shape with sizes from 1 to $100 \mathrm{~nm}$. In nanotechnology, a particle is called a small object that behaves as a single body with respect to its transport and physical properties (Thakkar et al., 2010). Their most important feature is the ratio of surface area to volume size, which allows them to more easily interact with other particles (Narayanan \& Sakthivel, 2010; Thakkar et al., 2010). For comparison, DNA strands have a diameter of $2.5 \mathrm{~nm}$ (Lyubchenko \& Shlyakhtenko, 1997), a typical virus of about $100 \mathrm{~nm}$ (Walkey, 2018), and a bacterium of about 1-3 $\mu \mathrm{m}$ wide (Katz et al., 2003). Occupying the intermediate position between individual atoms and molecules, nanoparticles exhibit fundamentally different physical and chemical properties compared to the macrocosm (Temerk et al., 2016; Wang et al., 2018a; Titus et al., 2019).

Today, worldwide production of MtNPs is estimated at $\$ 13.7$ billion, expected to reach $\$ 20$ billion by 2026 (Ovais et al., 2018a).

\section{Characterization of nanoparticles}

Numerous catalytically active nanomaterials of various origin are currently being created in the world (Cormode et al., 2018; Titus et al.,
2019), which include nanomaterials with enzyme-mimetic properties, as a potential alternative to natural enzymes and for use in immunoassay, biosensor, oncotherapy, pharmacy, food industry, ecology, etc. (Chen et al., 2012, 2014; Fu, 2014; Lu et al., 2015; Li \& Zhang, 2016; Tsekhmistrenko et al., 2018; Mu et al., 2019). Nanomaterial-based mimetics, compared to naturally occurring enzymes, have stability under harsh conditions, are capable of altering catalytic activity, and their production is relatively uncomplicated and economically justified, making them of great importance in practical applications (Wei \& Wang, 2013; Lin et al., 2014). The cyclicity of nanoparticles and their ability to recover without significant loss in subsequent cycles of catalytic activity make them unique compounds (Wei \& Wang, 2013). In addition, the surface of nanomaterials, unlike natural enzymes, which have only one active site in a molecule, may have more catalytic centers (Liu et al., 2015; Gao et al., 2017). Nanoparticles that can be used in biology and medicine should have low toxicity, or complete absence of toxicity, high biocompatibility, ability to biodegrade or be excreted naturally (Kozik et al., 2016; Bityutskyy et al., 2017; Chekman et al., 2017; Ovais et al., 2018b; Stoller et al., 2018; Yadi et al., 2018; Bityutskyy et al., 2019).

The significant adsorption activity of the nanoparticles, due to their increased specific surface area, allows them to absorb considerably more adsorbed substances per unit mass than macroscopic dispersions (Karakoti et al., 2012; Walser et al., 2012). The large specific surface area increases the adsorption capacity and adsorption on contaminant nanoparticles, facilitating their transport into cells (Karakoti et al., 2012). Nanomaterials are effective, inexpensive, and environmentally friendly alternatives to existing processing materials because they provide high efficiency and excellent characteristics such as high reaction rate and sur- 
face to mass ratio (Patanjali et al., 2019). Due to their small size, metal nanoparticles easily penetrate the body through the respiratory system, digestion, skin, overcome the biological barriers (hepatocellular, histochemical, placental), bind to nucleic acids and proteins, are embedded in cell membranes, penetrate into organelles with changes in their functions and exhibit more pronounced biological activity due to their large surface area per unit mass (Diegoli et al., 2008). Metal nanoparticles accumulate in plant and animal organisms, as well as in microorganisms transmitted through food chains, thereby increasing the flow to the human body.

The difference between the physical and chemical mechanisms of action of nanoparticles is explained by the surface arrangement of most atoms, which changes the physical, chemical, biological, toxicological properties of a substance and facilitates interaction with a living organism (Mikityuk, 2011). The target organs and reaction-response mechanisms are different for different metal nanoparticles. They are able to induce reactive oxygen species, disrupt membrane structures, penetrate tissue barriers, enter cells, and interact with intracellular components (Shakibaie et al., 2018). The question of the study of the positive effect and toxicity of metal nanoparticles is ambiguous and multifaceted and requires a comprehensive approach. This is especially true of nanoparticles used in pharmacology, medicine and agriculture, which contributes to their direct entry into the human body (Halliwell, 2006; Valko et al., 2006; Tsekhmistrenko et al., 2018a).

Therefore, the development of an environmentally friendly and inexpensive way to synthesize nanoparticles is crucial. There are numerous organisms capable of synthesizing nanoparticles and having the potential to use them (Das \& Chatterjee, 2019; Sanjay, 2019). Significant applications of nanomaterials are usually size dependent, so controlled synthesis of nanomaterials in size is highly desirable (Wang et al., 2017).

For the synthesis of nanoparticles by physical and chemical methods, it is necessary to use reducing agents that have a high reaction and toxic effect for human use or are environmentally hazardous, quite expensive (Shah et al., 2019). Large-scale synthesis also faces many problems, such as low stability and lower monodispersity (Manoj et al., 2018). Green synthesis (Fig. 1) involves the microbiota as a reducing agent such as bacteria, fungi, algae, viruses and plants (Pal et al., 2019).

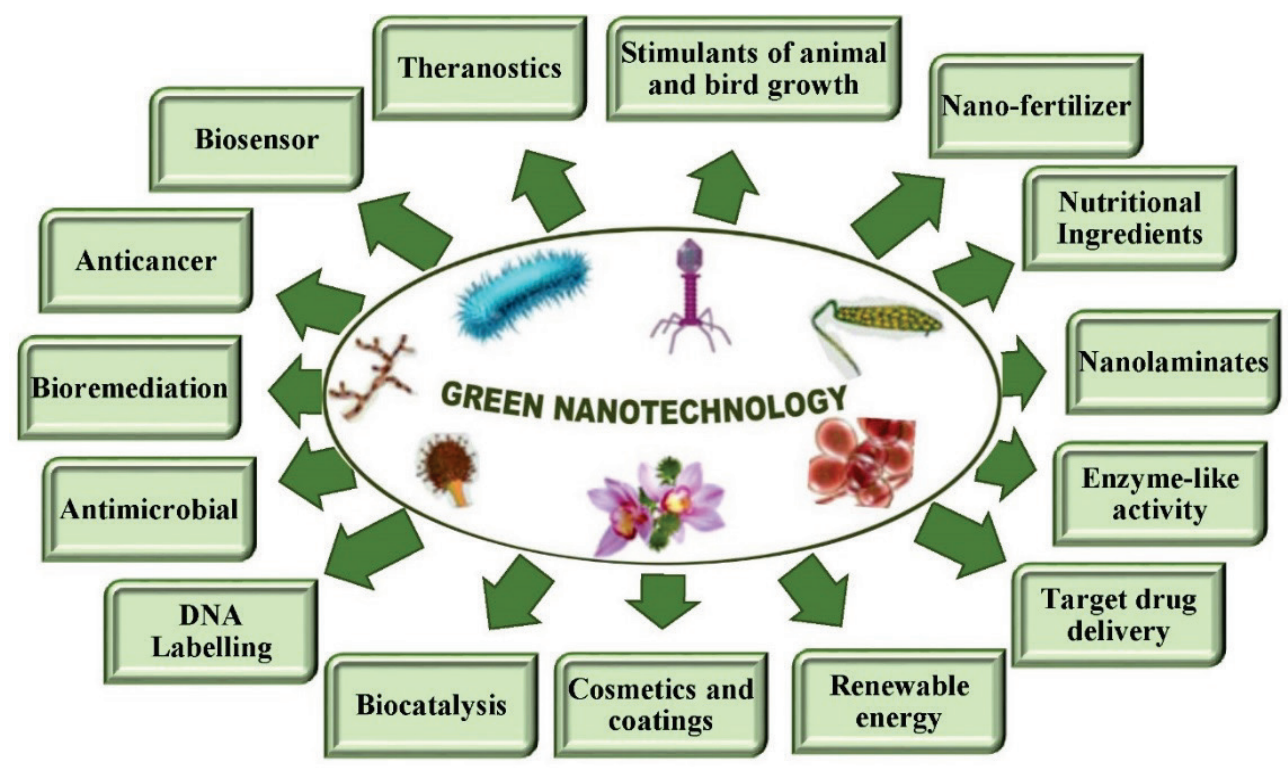

Fig. 1. Biosynthesized NPs pave the way for diverse applications of nanotechnology

Such "bionanofactories" are accessible to unique structures, are environmentally efficient, and have a high selective ability to absorb individual elements (Honary et al., 2012; Barabadi et al., 2017; Emmanuel et al., 2017). Compared to conventional approaches, biosynthetic NPs are better applied in different industries, in particular in drinking water treatment (Mekkawy et al., 2017; Patanjali et al., 2019). Toxic chemicals produced by nanoparticle synthesis can be metabolized by enzymes contained in microbiota and plants. Thanks to the "greening" of the synthesis process of nanoparticles, the use of biological systems and their components causes a reduction of environmental loading and increase of economic efficiency, opens additional possibilities of creation of nanoparticles with a given composition and properties. Each nanosystem is unique and specific in its formulation, compatibility with the active molecules, choice of excipients and kinetics, as well as biological efficiency (Dhapte \& Pokharkar, 2019).

Different microorganisms can synthesize nanoparticles intracellularly and extracellularly. In the case of intracellular synthesis due to electrostatic interaction, positively charged metal ions are attracted to the negatively charged bacterial cell membrane. In addition, the bacterial cell membrane contains enzymes that reduce metal ions to the corresponding nanoscale particles. In extracellular synthesis, the microbial cell secretes the reductases used in the bioreduction of metal ions into the corresponding MtNPs (Hulkoti \& Taranath, 2014).

Synthesis of nanoparticles with the participation of plants has been described in some detail in the literature (Singh et al., 2016). In this article, we will focus on the review of green NPs synthesis using potential microbial flora, including bacteria, fungi, yeast, microalgae and viruses.

\section{Eco-friendly synthesis of nanoparticles by bacteria}

Bacteria are known to be able to bind and concentrate dissolved metal and metalloid ions. Individual bacteria are capable of converting metal ions toxic to their life into non-toxic NPs (Garole et al., 2018; Fang et al., 2019). Given this, some bacteria are used as nanofactories, providing a new approach to the removal of metal or metalloid ions and the synthesis of materials with unique properties (Rautela et al., 2019). Among the methods of "green" synthesis bacteria are particularly important tools for obtaining NPs due to their diversity and high adaptability to extreme conditions (Wang et al., 2018c). Bacterial synthesis of NPs is extremely promising because of its low energy consumption and process controllability (Fang et al., 2019). NPs of metals can be formed by bacteria both intracellularly and extracellularly. Extracellular synthesis has been found to be more efficient and easier for extraction of NPs. In this case, biosynthetic metal NPs are more resistant to oxidation, which makes it possible to use them in various fields (Gahlawat et al., 2019).

Currently, a number of reports have accumulated regarding the synthesis of metal nanoparticles by various bacteria. Thus, $\mathrm{ZnO}$ nanoparticles were synthesized with the participation of Lactobacillus plantarum (Selvarajan \& Mohanasrinivasan, 2013) and Aeromonas hydrophila (Jayaseelan et al., 2012). Antimicrobial activity against E. coli and S. aureus is exhibited by $\mathrm{CuO}$ nanoparticles formed with the participation of Halomonas elongata (Rad et al., 2018). Iron oxide nanoparticles obtained using Bacillus cereus had dose-dependent anticancer effects against MCF-7 and 3 T3 cell lines (Fatemi et al., 2018). Pd nanoparticles 
synthesized by Alpine Pseudomonas exhibited catalytic activity in dechlorination reactions (Schlüter et al., 2014). Silver nanoparticles are capable of producing various bacteria, including lactic acid bacteria (Sintubin et al., 2009), Bacillus licheniformis (Kalimuthu et al., 2008; Kalishwaralal et al., 2010). Cyanobacterial silver nanoparticles have the potential to bind ammonia (Tomer et al., 2019). Biosynthesis of silver nanoparticles has been reported using $\mathrm{AgNO}_{3}$ as a precursor to Bacillus amyloliquefaciens and Bacillus subtillis (Ghiuță et al., 2018; Yurtluk et al., 2018). The antibacterial activity of the nanoparticles was observed after $24 \mathrm{~h}$ incubation against gram-negative bacteria: Escherichia coli, Pseudomonas aeruginosa, Salmonella, and gram-positive: Staphylococcus aureus, Streptococcus pyogenes. In addition, their antifungal activity against Candida albicans was detected. We obtained AgNPs with the participation of Bacillus pumilus, Bacillus paralicheniformis and Sphingomonas paucimobilis of spherical and ovalform with a particle size of 4-20 nm and a surface area of $118 \mathrm{~m}^{2} / \mathrm{g}$ (Allam et al., 2019). The silver nanoparticles obtained from the Streptacidiphilus durhamensis HGG16n isolate had a size of 8-48 nm (Buszewski et al., 2018). Bacillus endophyticus (Gan et al., 2018) and Deinococcus radiodurans (Li et al., 2018) are capable of producing silver nanoparticles of various shapes and sizes.

Bacteria of various species are capable of accumulating nanoparticles of cuprum, in particular Shewanella loihica (Lv et al., 2018), Bacillus sp. FU4 (Taran et al., 2017), Shewanella oneidensis (Kimber et al., 2018). Platinum nanoparticles were obtained by green synthesis with the participation of Streptomyces sp. (Sharma, 2017), Magnesium Lactobacillus sp. (Mohanasrinivasan et al., 2018), bismuth - Delftia sp. SFG (Shakibaie et al., 2018).

Bacteria Lysinibacillus sp. and Pseudomonas stutzeri, which were adapted to alkaline conditions, can be used for efficient biosynthesis of AuNPs, which exhibits potential biomedical use (San Diego et al., 2019). AuNPs nanoparticles obtained using Lyngby Majuscule are used to prevent myocardial infarction (Bakir et al., 2018). Marine bacteria Marinobacter algicola formed various types of AuNPs at $\mathrm{pH} 7.0$, at $30^{\circ} \mathrm{C}$ in the presence of nitrate reductase, such as spherical, triangular, pentagonal and hexagonal with the average size of 4-168 nm (Gupta \& Padmanabhan, 2018). Extracellular recovery of palladium to PdNPs was performed using Geobacter sulfurreducens (Yates et al., 2013), Shewanella oneidensis MR-1 (Wu et al., 2018), Shewanella sp. CNZ-1 (Zhang \& Hu, 2017), S. loihica PV-4 (Wang et al., 2018b), Bacillus sp. GP (Zhang \& Hu, 2018).

A number of studies had shown that not only living bacteria but also the dead forms of some bacteria can also be used for the biosynthesis of NPs. However, the mechanisms of these processes differ. As a rule, the metabolic process may be responsible for the bioreduction of NPs in living bacteria (Reverberi et al., 2017; Allam et al., 2019).

Recently, more and more bacteria have been used for the synthesis of selenium, which is widely used in agriculture, the use of which increases the productivity of animals and poultry much better than inorganic forms (Singh \& Singh, 2019; Tsekhmistrenko et al., 2019). For this purpose, Rhodococcus aetherivorans BCP1 (Presentato et al., 2018), Acinetobacter sp. SW 30 (Wadhwani et al., 2018), Rahnella aquatilis HX2 (Zhu et al., 2018), Alcaligenes sp. CKCr-6A (Mesbahi-Nowrouzi \& Mollania, 2018), Alishewanella sp. WH16-1 (Xia et al., 2018), Bacillus subtilis IMV B-7392 (Tymoshok et al., 2019) were used.

\section{Mechanisms of synthesis of nanoparticles by bacteria}

Specific mechanisms of NPs formation in different organisms, both in unicellular and multicellular, have been established. However, the synthesis of NPs follows a generalized scheme in which metal ions are captured by microbial cells or pooled to the size of NPs in the presence of an enzyme (Yin et al., 2016).

Nanoparticle biosynthesis is carried out by culturing microorganisms in specific nutrient media containing the corresponding ions. Depending on the localization site, the synthesis of nanoparticles by microorganisms (in particular bacteria, fungi, actinomycetes, yeast and even viruses) is classified into intracellular and extracellular (Shankar et al., 2016). Metal ions enter the bacterial cell through ion channels, through active transport, endocytosis, or penetration through the lipid membrane (Grzelczak \& Liz-Marzán, 2014). The process of intracellular synthesis involves the process of trapping, bioreduction, and capping of various nanoparticles (Li et al., 2011a). Extracellular synthesis consists of enzyme secretion, bioreduction and particle capping (Singh \& Singh, 2019). Most published reports (Singh, 2015; Banerjee \& Rai, 2018) have argued that extracellular nanoparticle synthesis is preferable because low-flow and purification processes are easier compared to intracellular methods. Most published works (Singh, 2015) argue that extracellular nanoparticle synthesis is preferable because downstream and purification processes are easier than intracellular methods. One commonly used enzyme is nitrate reductase, which may be responsible for the synthesis of nanoparticles, such as silver and gold nanoparticles.

In the process of bioreduction (Fig. 2), individual enzymes play an important role in the transport of electrons from donors to the positive metal ion (Siddiqi et al., 2018).

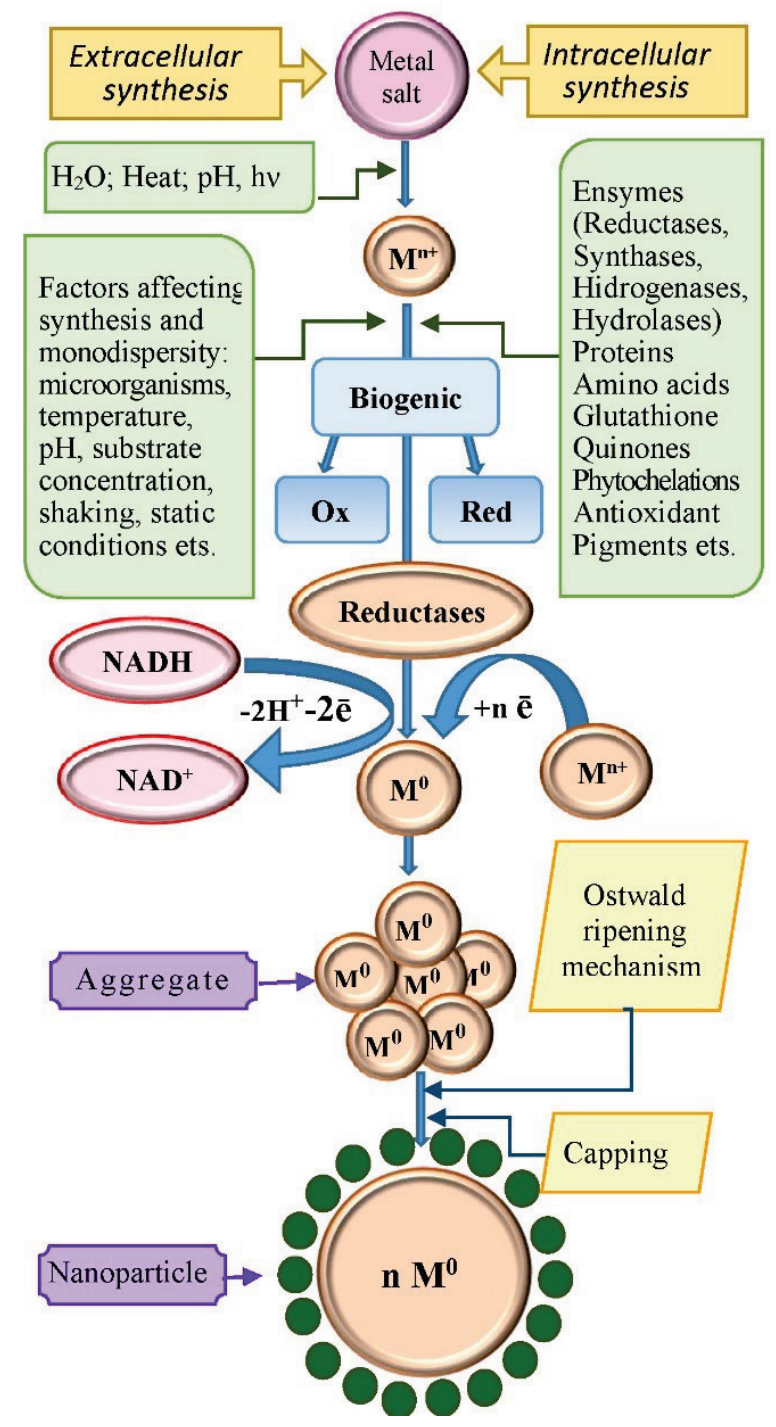

Fig. 2. General scheme of synthesis of nanoparticles of metals by microorganisms

Some bacterial protein functional groups $\left(-\mathrm{NH}_{2},-\mathrm{OH},-\mathrm{SH}\right.$, and $-\mathrm{COOH}$ ) play an important role in the formation and stabilization of NPs. They provide binding sites for fixation of metal ions with further reduction of their extracellular concentration and localization on the cell wall or in the periplasmic space. Synthesis of Au-NPs gold nanoparticles has been reported on Deinococcus radiodurans protein extract (Li et al., 2018). Free cysteine and surface-bound microbial protein are involved in the stabilization of NPs, which prevents their aggregation (Zakaria et al., 2013). Supernatants of Enterobacteriaceae culture are characterized by significant activity of the nitroreductase enzyme, which is involved in bacterially mediated synthesis of Au-NPs (Ramezani et al., 2010).

Pathways related to green nanomaterial synthesis are of paramount importance for commercializing nanotechnology as well as for environ- 
mental sustainability (Nasrollahzadeh et al., 2019). Synthesis mechanisms will also improve the processes of bioremediation and biomineralization of pollutants in the environment. Biomineralization is the maximum process of controlling the final fraction in the biogeochemical cycle and environmental impact of heavy metals (Diaz et al., 2015). Understanding the pathways of microbial transformation at the genetic level may lead to the development of new genetic tools to accelerate bioremediation strategies (Wu et al., 2016; Kang et al., 2017).

Alternative ways of synthesis of nanoparticles have been established. The likely mechanism of nanoparticle biosynthesis may include more than one cellular component (Ovais et al., 2018b). It is believed that nitrate reductase acts as a principal reducing agent in the transformation of metals into nanoparticles (Gupta \& Padmanabhan 2018; Ali et al., 2019). Reducing the amount of metal ions, in particular $\mathrm{Ag}^{+}$, is the process of enzymatic reduction by electron transport. Cofactors such as $\mathrm{NADH}$ in NADH-dependent nitrate reductase enzymes are required to generate metallic LFs (Kalimuthu et al., 2008; Kalishwaralal et al., 2010). According to other researchers (Sintubin et al., 2009; Li et al., 2011), the increase in $\mathrm{pH}$ directly correlates with competition for the negatively charged binding site between the metal ion and protons.

The synthesis of AgNPs from probiotic tablets and yoghurt mediated by Lactobacillus has also been reported. Lactate from NADH, depending on the lactate dehydrogenase and pyruvate, generates two protons involved in the synthesis process along with thioredoxin systems and glutathione. All components work in concert to facilitate the synthesis of nanoparticles (Nangia et al., 2009).

The effect of visible light on the production of AgNPs has been investigated, especially in the processing of Klebsiella and silver nitrate by visible light, which has led to changes in the rate of their synthesis (Mokhtari et al., 2009). It is suggested that the accumulation of silver outside the cell membrane of bacteria is associated with the response to the potential with gaseous $\mathrm{H}_{2} \mathrm{~S}$, which transformed it into a non-toxic form by Pseudomonas cells (Klaus et al., 1999). The bioreduction of ionic silver in AgNPs is due to the cofactor and enzyme nitrate reductase released by Bacillus licheniformis. Optimization in activity and production has confirmed the hypothesis that catalytic proteins are involved in recovery and synthesis (Vaidyanathan et al., 2010). However, bacterial interaction with different metals is not yet fully understood.

The role of peptides and individual amino acids in the microbial synthesis of AgNPs nanoparticles has been proved. By adding peptides to the silver ion solution, they reacted with metallic ion nuclei and reduced accessibility around metal nanoclusters (Naik et al., 2002; Balachandran et al., 2013). Peptides containing the amino acids cysteine, methionine, arginine and lysine can attach to the nucleus surface and be used in the production of AgNPs (Selvakannan et al., 2013). The amino acid tyrosine under alkaline conditions acts as a reducing agent. This is due to the fact that the phenolic group of tyrosine can be converted to the group of quinone (Selvakannan et al., 2004; Dubey et al., 2015). In addition, tyrosine-containing oligopeptides at the free $\mathrm{N}$-terminus provide stability to the nanoparticles (Shankar et al., 2015) and promote metal recovery (Daima et al., 2014). These results are consistent with the notion that tyrosine plays a key role in in situ reduction (Ali et al., 2019).

The amino acid tryptophan can be used as a reducing agent for the synthesis of nanoparticles because of its ability to give electrons. In this case, tryptophan becomes a tryptophol radical ( $\mathrm{Si} \&$ Mandal, 2007). Aspartic acid and glutamic acid are involved in the synthesis of AgNPs nanoparticles in the presence of carboxyl groups of short yeast peptides.

Enzymes can play a major role in the recovery of metal salts with the subsequent formation of metal NPs. Optimization of various parameters can improve the synthesis of AgNPs. By controlling the mechanistic steps, the monodispersity and homogeneity of the nanoparticles are achieved (Ali et al., 2019).

The role of NADH or NADH-dependent enzymes released extracellularly for the formation of gold nanoparticles using the Rhodopseudomonas culture have been established (He et al., 2007). Electrons are transmitted via NADH-dependent reductase to $\mathrm{Au}^{3+}$ gold ions, converting them to elemental gold $\left(\mathrm{Au}^{0}\right)$ (Nangia et al., 2009). The biosynthesis of Au nanoparticles is activated with the participation of peptides that act as a stabilizing agent (Singaravelu et al., 2007; Das \& Marsili, 2010). Synthesis of platinum nanoparticles was carried out with the participa- tion of a hydrogenase enzyme extracted from sulfate-reducing bacteria (Martins et al., 2017). Various microbes serve as nanofactories for the synthesis of platinum nanoparticles (PtNPs), in particular Desulfovibrio vulgaris, Acinetobacter calcoaceticus (Gaidhani et al., 2014), Shewanella (Martins et al., 2017). The nanoparticles are localized within the periplasmic membranes.

Chelating agents, such as siderophores, bind heavy metal ions to form gaseous compounds. Low molecular weight tripeptide glutathione, metallothioneins containing cystine-rich proteins isolated from Syneococcus sp., Pseudomonas putida, Cyanobacterium and E. coli, perform the major function of metal detoxification.

Aerobic biosynthesis of monodisperse nanosized Se-NPs is carried out both intracellularly and extracellularly by Enterobacter cloacae Z0206 with the participation of a selenite-reducing factor, which is a special form of fumarate reductase (Shin et al., 2009). Selenium nanoparticles are obtained with the participation of Pseudomonas putida, which is a strictly aerobic species, and no substrate other than oxygen serves as the ultimate electron acceptor. The proposed mechanism is a two-step process that included chelation of $\mathrm{SeO}_{3}{ }^{2-}$ thiol-containing molecules with subsequent formation of selenodiglutathione. Selenodiglutathione is a substrate of glutathione reductase that produces unstable intermediates (Avendaño et al., 2016; Wang et al., 2017a).

Cytochrome is involved in the bacterial synthesis of NPs. Thus, the pigment Chryseobacterium artocarpi CECT 8497 is used to create coexisting spherical Ag-NPs (Venil et al., 2016). Biosynthesis of extracellular Cu-NPs from Shewanella loihica PV-4 as electron donors for $\mathrm{Cu}^{2+}$ used cytoplasmic components such as NADH/NADPH, vitamins and organic acids. Cytochrome $\mathrm{c}$ for electron transfer was the primary reducing factor (Lv et al., 2018).

Lactate was used as an electron donor to form CuNPs from Shewanella oneidensis MR1. Reductase in the periplasm and cytoplasm promotes the conversion of $\mathrm{Cu}^{2+}$ to $\mathrm{Cu}^{0}$. Damage to the membrane due to $\mathrm{Cu}$ toxicity can promote the transport of NPs through the cytoplasmic membrane. $\mathrm{Cu}^{2+}$ can be converted to $\mathrm{Cu}^{+}$in the cytoplasm and then $\mathrm{Cu}^{+}$ is able to disproportionately form $\mathrm{Cu}^{2+}$ and $\mathrm{Cu}$ (Kimber et al., 2018).

Studies on E. coli and Staphylococcus aureus have shown that silver ions condense to nanoparticles and accumulate around the cell wall or inside the cell and affect DNA replication and interact with thiol groups, causing protein inactivation (Feng et al., 2000). It also leads to the formation of reactive oxygen species (Matsumura et al., 2003).

The production and overuse of synthetic dyes, pesticides and pharmaceuticals have led to environmental pollution (Doshi et al., 2018; Hu et al., 2018; Allam et al., 2019; Singh et al., 2019). Contaminated sewage and soil usually contain large amounts of heavy metals and metalloids (Choi et al., 2018). Alternatively, however, waste can also be used as a resource for the production of NPs through a biological pathway for the degradation of specific pollutants (Chen et al., 2014; Huang et al., 2018).

The marine bacterium Pseudoalteromonas sp CF10-13 is potentially effective in the bleaching and degradation of Naphthol Green B (NGB) metal complex in a wide range of salinity, dye concentration and alkalinity under anaerobic conditions. Naphthalenesulfonate, the basic structure in the NGB molecule, is further decomposed into low-toxic benzamide (Cheng et al., 2019).

B. paralicheniformis strain $\mathrm{KJ}-16$ was the most effective isolated bacteria to provide an extract for AgNPs biosynthesis and dye removal. This method may be considered easy and eco-friendly, and could be applicable for large-scale decontamination of wastewater from harmful dyes (Nayna \& Tareq, 2019).

Copper nanoparticles $(\mathrm{NCu})$ have been proposed as an antimicrobial agent in agriculture because they can interact with numerous contaminants, including pesticides, in particular atrazine (Parada et al., 2019).

Various reducing and oxidation methods are used to neutralize chlorinated aromatic compounds, which are widely used in many industries. An efficient and easy treatment of these xenobiotics is the treatment of their biosynthetic Pd-based NPs. The cell surfaces of Desulfovibrio desulfuricans, Desulfovibrio vulgaris were used to fabricate a new bioorganic catalyst by reducing $\mathrm{Pd}^{2+}$ to $\mathrm{Pd}^{0}$ on the cell surface using hydrogen as an electron donor. The rate of dechlorination of bioPd-NPs was approximately 30 times higher than that of chemical PdNPs (Baxter-Plant et al., 2003). Positive results for 4-nitrophenol neutra- 
lization were obtained with the use of Pd/Au-NPs formed by the marine bacterium Bacillus sp. GP (Zhang et al., 2017).

Alternatively, waste can be used as a resource for the production of NPs through a biological pathway for the degradation of specific pollutants (Huang et al., 2018; Seifan et al., 2018; Zhang et al., 2018).

The interaction of nanoparticles and germs plays an important role in the treatment of various diseases in the form of antimicrobial agents. The mechanism of inhibition of metabolism of various bacteria and fungi by nanoparticles involves a number of pathways. Metal ions that form nanoparticles inside cells promote the degradation of intracellular ATP and interrupt DNA duplication (Lok et al., 2006). NPs generate reactive oxygen species (ROS), which causes damage to cellular structures (Kim et al., 2007). Nanoparticles are accumulated and dissolved in the bacterial membrane, which leads to changes in membrane permeability, there is a gradual release of lipopolysaccharides, membrane proteins and intracellular components and dispersion of proton motive force (PMF). Oxidation reactions affect cell survival, cell death, differentiation, cell signaling and lead to the generation of ROS under stress (Mueller et al., 2005; Touyz, 2005). The various components of reactive oxygen species include free radicals such as superoxide $\left(\mathrm{O}_{2}{ }^{\circ}\right)$, singlet oxygen $\left(\mathrm{O}_{2}\right)$, hydroxyl $\left(\mathrm{HO}^{\circ}\right)$, hydroperoxyl $\left(\mathrm{HO}_{2}{ }^{\circ}\right)$, carbon dioxide $\left(\mathrm{CO}_{2}\right)$, carbonate $\left(\mathrm{CO}_{3}{ }^{\circ}\right)$, peroxyl $\left(\mathrm{RO}_{2}{ }^{\circ}\right)$ and alkoxyl $\left.(\mathrm{RO})^{\circ}\right)$ and nonradical substances such as ozone $\left(\mathrm{O}_{3}\right)$, hydrogen peroxide $\left(\mathrm{H}_{2} \mathrm{O}_{2}\right)$, nitric oxide (NO), hydrochloric acid ( $\mathrm{HOCl})$, hypochlorite $\left(\mathrm{OCl}^{-}\right)$, hypobromic acid $(\mathrm{HOBr})$, organic peroxides $(\mathrm{ROOH})$, peroxynitrite $\left(\mathrm{ONOO}^{-}\right)$, peroxynitrate $\left(\mathrm{O}_{2} \mathrm{NOO}^{-}\right)$, peroxinic acid $(\mathrm{ONOOH})$, and peroxomonocarbonate $\left(\mathrm{HOOCO}^{-}\right)$(Halliwell, 2006; Pantopoulos \& Schipper, 2012; Wu et al., 2014).

Superoxide produced by nicotinamide dinucleotide phosphate (NADPH), oxidase (NOX) and mitochondria inactivates various enzymes and initiates peroxide oxidation of cell membrane lipids (Singh \& Singh, 2019). Under various physiological conditions, intracellular stages are rigorously modulated by various detoxifying enzymes, such as SOD, catalase, and glutathione peroxidase, or by various antioxidant compounds, including ascorbic acid, vitamin E, flavonoids and glutathione (Wu et al., 2014).

Nanoparticles (silver, zinc oxide and copper oxide) activate ROS synthesis, which directly and indirectly play an important role in genotoxicity. DNA degradation caused by oxidative stress destabilizes a variety of biological mechanisms, including mutagenesis (Fu et al., 2014a). DNA damage causes disruption of the structure of nitrogenous bases, sugars, single and double breaks, DNA protein crosslinks, etc. (Valko et al., 2006; Fu et al., 2014a).

The main disadvantage of using a microbial source is the maintenance of aseptic conditions, the high cost of isolation and their maintenance in culture media (Rautela et al., 2019). NPs synthesized by bacteria without high-temperature treatment or additional of chemicals have many unique properties. Due to their biocompatibility and stability, they are a real alternative to the physical and chemical methods traditionally used in catalysis (Jiang et al., 2018; Patanjali et al., 2019).

\section{Prospects for the use of nanoparticles}

The need for a comprehensive study of nanoparticles (metals and non-metals) is due to the considerable amount of scientific research, which has shown that their properties differ significantly from similar macroparticles and from the substances from which they were obtained (Nasrollahzadeh et al., 2019). These properties depend on their composition, nature, shape, size, charge, structural features, both the surface of the nanoparticle itself and the surface modifier molecules (if used), the preparation methods, and the process parameters (Gupta \& Padmanabhan, 2018). There are many aspects of these biological methods that can be detected and then manipulated (Dhapte \& Pokharkar, 2019). Nanobiotechnologies, based on the use of bacteria, contribute to the reduction of nanoparticles, have high commercial potential with the prospects of widespread use. The nanoparticles obtained in this way show better biocompatibility due to the absence of adsorbed toxic substances. Much of the experimental research has been conducted to create diagnostic and therapeutic nanosheets (Barabadi et al., 2017; Bakir et al., 2018; Mohanasrinivasan et al., 2018).
Specialists of various profiles - material scientists, chemists, biologists, physicians and veterinarians - are involved in this problem $(\mathrm{Pal}$ et al., 2019). The purpose of these studies is to create nanoparticles, not as a final product, but as a feedstock for biocompatible substances. Compared to conventional pathway NPs, biosynthetic NPs have some unique properties and can be used without side effects in areas such as catalysis and degradation of organic pollutants (Liu et al., 2015a; Naim et al., 2016). Priority research is to determine the effects of the impact of MeNPs on any biological entity that is required when designing biotechnology products with the involvement of nanotechnology. Such studies can only be adequate with the consistent use of biomarkers key systemic characteristics of a living organism (biochemical, physiological, immunological, etc.). Several basic mechanisms of contact interaction of metals in different chemical forms on the model of cells of microorganisms are described. The mechanism of passive deposition of metals by a bacterial cell is based on the physical and chemical binding of the structural components of the cell membrane. Metabolism-dependent cumulation of metals is associated with the functioning of cellular enzyme systems that provide metabolism and energy responses to the environment. Prokaryotic cells, due to their unique structural properties and metabolism, are able to actively interact with metals and can be a model system for studying the relationship between a cell and MeNPs.

\section{Potential danger of using nanoparticles}

The potential hazards and biocompatibility of MeNPs are mostly individual for different strains within one taxonomic species of microorganism; on the other hand it is difficult to isolate the specific mechanisms of biocompatibility or cytotoxic action of MeNPs, as they can vary greatly even within the same class of nanomaterials, so this question is still debatable (Das \& Chatterjee, 2019). The effective sizes and concentrations of MeNPs have been proved, in which the effect on the structural and functional level is observed. MeNPs, depending on the size and concentration of metal cations, can affect the activity of many enzymes, including membrane bound ones (Fu et al., 2014). A particular problem is the handling of nanoparticles and nanomaterials, which can cause unusual effects on human health. Because the nanoparticles are small in size, it can allow them to penetrate the human organs and tissues, bypassing the normal biological barrier (Sanjay, 2019).

The study of the influence of various factors on the structural and functional state of bacterial cells is of interest for understanding the regulation of metabolism during adaptation. Determining critical points in the phases of microbial population development, in particular when maximum target product accumulation occurs, as well as the search for substances that could directly influence the management of physiological and biochemical responses of population cells, is becoming a central task of applied biochemistry and biotechnology research. One of the main steps in the application of each MeNPs as a potential substance is a comprehensive assessment of their biological safety in each case. Compared to others, the pharmacological effects of MeNPs have significant advantages in their ability to biodegrade. The pharmacodynamics of MeNPs are due to their physicochemical properties. However, the pharmacokinetic and toxicokinetic action of MeNPs in any cell, organ, and organism requires detailed study, lacks data on target organs, penetration through biological membranes, and bioavailability. The indirect danger of MeNPs is due to their cytogenotoxicity, ability to cause inflammation and oxidative stress at the cellular level. Such studies should include the determination of MeNPs safety in the in vitro system followed by toxicological experiments in the in vivo system that include testing for genotoxicity, mutagenicity, biocompatibility and bioavailability by determining the genetic, biochemical and cytological markers of the biological potential of the organization.

It is promising to study the systemic response of macroorganisms to the action of nanoparticles, which in general may differ significantly from the results obtained in experiments on isolated cells. Research should be based on more data, including preclinical animal testing using a set of systemic markers (physiological, biochemical, immunological, etc.), including long-term (chronic) ones.

Finally, major issues such as mass production, leaching, poisoning/ toxicity, regeneration, reuse and production costs, process optimization 
are major barriers to the transfer of nanoparticles based on the use of nanoparticles from laboratory to commercial scale (Ali et al., 2019a; Goutam et al., 2020).

\section{Conclusion}

This paper presents separate results on the general characteristics of nanoparticles and their production by the use of green chemistry methods. The prospect of using bacteria as a kind of "biofactory" for the synthesis of metal nanoparticles and essential elements is shown.

The vast array of scientific research shows that nanoparticles are nowadays characterized by a wide range of applications, in particular in engineering, biology, medicine, agriculture, the food industry and the like. It is proved that nanoparticles exhibit high biological activity due to a number of factors that must be taken into account in order to target them. Eco-friendly synthesis methods should aim at creating predictable, standardized systems. At the same time, samples of biogenic nanoparticles will become more homogeneous and reproducible, so the risks to the environment and health will be minimized. The aspects of the interaction of nanoparticles and biological molecules, in particular with proteins, carbohydrates and lipids, remain multifaceted. For more practical use of nanoparticles in biology and medicine, it is necessary to focus on their metabolism in humans and animals (Grillone et al., 2017; Tsekhmistrenko et al., 2019). It is promising to study the possibility of synthesis of nanoparticles of different elements by one type of bacteria, which raises a number of new questions and problems.

Research into the direction of nanoparticle synthesis and application requires a comprehensive, safe and responsible approach to assessing potential health and environmental risks, which underpins European Union policy on nanotechnology (Rauscher et al., 2012).

\section{References}

Ali, I., Peng, C., Khan, Z. M., Naz, I., Sultan, M., Ali, M., Abbasi, I. A., Islam, T. \& Ye, T. (2019a). Overview of microbes based fabricated biogenic nanoparticles for water and wastewater treatment. Journal of Environmental Management, 230, 128-150.

Ali, J., Ali, N., Wang, L., Waseem, H., \& Pan, G. (2019). Revisiting the mechanistic pathways for bacterial mediated synthesis of noble metal nanoparticles. Journal of Microbiological Methods, 159, 18-25.

Allam, N. G., Ismail, G. A., El-Gemizy, W. M., \& Salem, M. A. (2019). Biosynthesis of silver nanoparticles by cell-free extracts from some bacteria species for dye removal from wastewater. Biotechnology Letters, 41(3), 379-389.

Avendaño, R., Chaves, N., Fuentes, P., Sánchez, E., Jiménez, J. I., Chavarría, M. (2016). Production of selenium nanoparticles in Pseudomonas putida KT2440. Scientific Reports, 6, 1-9.

Bakir, E., Younis, N., Mohamed, M., \& El Semary, N. (2018). Cyanobacteria as nanogold factories: Chemical and anti-myocardial infarction properties of gold nanoparticles synthesized by Lyngbya majuscula. Marine Drugs, 16(6), 217.

Balachandran, Y. L., Girija, S., Selvakumar, R., Tongpim, S., Gutleb, A. C., \& Suriyanarayanan, S. (2013). Differently environment stable bio-silver nanoparticles: Study on their optical enhancing and antibacterial properties. PLoS One, 8(10), e77043

Banerjee, K., \& Rai, V. R. (2018). A review on mycosynthesis, mechanism, and characterization of silver and gold nanoparticles. BioNanoScience, 8(1), 17-31.

Barabadi, H., Ovais, M., Shinwari, Z. K., \& Saravanan, M. (2017). Anti-cancer green bionanomaterials: present status and future prospects. Green Chemistry Letters and Reviews, 10(4), 285-314.

Baxter-Plant, V. S., Mikheenko, I. P., \& Macaskie, L. E. (2003). Sulphate-reducing bacteria, palladium and the reductive dehalogenation of chlorinated aromatic compounds. Biodegradation, 14(2), 83-90.

Bityutskyy, V. S., Tsekhmistrenko, O. S., Tsekhmistrenko, S. I., Spyvack, M. Y., \& Shadura, U. M. (2017). Perspectives of cerium nanoparticles use in agriculture. The Animal Biology, 19(3), 9-17.

Bityutskyy, V., Tsekhmistrenko, S., Tsekhmistrenko, O., Melnychenko, O., \& Kharchyshyn, V. (2019). Effects of different dietary selenium sources including probiotics mixture on growth performance, feed utilization and serum biochemical profile of quails. Modern Development Paths of Agricultural Production. Springer, Cham. Pp. 623-632.

Buszewski, B., Railean-Plugaru, V., Pomastowski, P., Rafińska, K., SzultkaMlynska, M., Golinska, P., Wypij, M., Laskowski, D., \& Dahm, H. (2018). Antimicrobial activity of biosilver nanoparticles produced by a novel Streptacidiphilus durhamensis strain. Journal of Microbiology, Immunology and Infection, 51(1), 45-54.
Chekman, I. S., Horchakova, N. O., \& Simonov, P. V. (2017). Biologically active substances as nanostructures: A biochemical aspect. Klìnična Farmaciâ, 21(2), 15-22.

Chen, H., Seiber, J. N., \& Hotze, M. (2014). ACS select on nanotechnology in food and agriculture: A perspective on implications and applications. Journal Agricultural and Food Chemistry, 62(6), 1209-1212.

Chen, Z., Yin, J. J., Zhou, Y. T., Zhang, Y., Song, L., Song, M., Hu, S., \& Gu, N (2012). Dual enzyme-like activities of iron oxide nanoparticles and their implication for diminishing cytotoxicity. ACS Nano, 6(5), 4001-4012.

Cheng, S., Li, N., Jiang, L., Li, Y., Xu, B., \& Zhou, W. (2019). Biodegradation of metal complex Naphthol Green B and formation of iron-sulfur nanoparticles by marine bacterium Pseudoalteromonas sp CF10-13. Bioresource Technology, 273, 49-55.

Choi, S., Johnston, M., Wang, G. S., \& Huang, C. P. (2018). A seasonal observation on the distribution of engineered nanoparticles in municipal wastewater treatment systems exemplified by $\mathrm{TiO}_{2}$ and $\mathrm{ZnO}$. Science of the Total Environment, 625, 1321-1329.

Cormode, D. P., Gao, L., \& Koo, H. (2018). Emerging biomedical applications of enzyme-like catalytic nanomaterials. Trends in Biotechnology, 36(1), 15-29.

Daima, H. K., Selvakannan, P. R., Kandjani, A. E., Shukla, R., Bhargava, S. K., \& Bansal, V. (2014). Synergistic influence of polyoxometalate surface corona towards enhancing the antibacterial performance of tyrosine-capped Ag nanoparticles. Nanoscale, 6(2), 758-765.

Das, M., \& Chatterjee, S. (2019). Green synthesis of metal/metal oxide nanoparticles toward biomedical applications: Boon or bane. In: Shukla, A. K., \& Iravani, S. (Eds.). Green synthesis, characterization and applications of nanoparticles. Elsevier. Pp. 265-301.

Das, S. K., \& Marsili, E. (2010). A green chemical approach for the synthesis of gold nanoparticles: Characterization and mechanistic aspect. Reviews in Environmental Science and Bio/Technology, 9(3), 199-204.

Dhapte, V., \& Pokharkar, V. (2019). Nanosystems for drug delivery: Design, engineering, and applications. In: Shukla, A. K., \& Iravani, S. (Eds.). Green Synthesis, Characterization and Applications of Nanoparticles. Elsevier, Pp. 321-345.

Diaz, M. R., Swart, P. K., Eberli, G. P., Oehlert, A. M., Devlin, Q., Saeid, A., \& Altabet, M. A. (2015). Geochemical evidence of microbial activity within ooids. Sedimentology, 62(7), 2090-2112.

Diegoli, S., Manciulea, A. L., Begum, S., Jones, I. P., Lead, J. R., \& Preece, J. A. (2008). Interaction between manufactured gold nanoparticles and naturally occurring organic macromolecules. Science of the Total Environment, 402(1), $51-61$.

Doshi, B., Sillanpää, M., \& Kalliola, S. (2018). A review of bio-based materials for oil spill treatment. Water Research, 135, 262-277.

Dubey, K., Anand, B. G., Badhwar, R., Bagler, G., Navya, P. N., Daima, H. K., \& Kar, K. (2015). Tyrosine-and tryptophan-coated gold nanoparticles inhibit amyloid aggregation of insulin. Amino Acids, 47(12), 2551-2560.

Emmanuel, R., Saravanan, M., Ovais, M., Padmavathy, S., Shinwari, Z. K., \& Prakash, P. (2017). Antimicrobial efficacy of drug blended biosynthesized colloidal gold nanoparticles from Justicia glauca against oral pathogens: A nanoantibiotic approach. Microbial Pathogenesis, 113, 295-302.

Fang, X., Wang, Y., Wang, Z., Jiang, Z., \& Dong, M. (2019). Microorganism assisted synthesized nanoparticles for catalytic applications. Energies, 12(1), 190.

Fatemi, M., Mollania, N., Momeni-Moghaddam, M., \& Sadeghifar, F. (2018). Extracellular biosynthesis of magnetic iron oxide nanoparticles by Bacillus cereus strain HMH1: Characterization and in vitro cytotoxicity analysis on MCF-7 and 3T3 cell lines. Journal of Biotechnology, 270, 1-11.

Feng, Q. L., Wu, J., Chen, G. Q., Cui, F. Z., Kim, T. N., \& Kim, J. O. (2000). A mechanistic study of the antibacterial effect of silver ions on Escherichia coli and Staphylococcus aureus. Journal of Biomedical Materials Research, 52(4), 662-668.

$\mathrm{Fu}, \mathrm{P}$. P. (2014). Introduction to the special issue: nanomaterials-toxicology and medical applications. Journal of Food and Drug Analysis, 22(1), 1-2.

Fu, P. P., Xia, Q., Hwang, H. M., Ray, P. C., \& Yu, H. (2014a). Mechanisms of nanotoxicity: Generation of reactive oxygen species. Journal of Food and Drug Analysis, 22(1), 64-75.

Gahlawat, G., \& Choudhury, A. R. (2019). A review on the biosynthesis of metal and metal salt nanoparticles by microbes. RSC Advances, 9(23), 12944-12967.

Gaidhani, S. V., Yeshvekar, R. K., Shedbalkar, U. U., Bellare, J. H., \& Chopade, B. A. (2014). Bio-reduction of hexachloroplatinic acid to platinum nanoparticles employing Acinetobacter calcoaceticus. Process Biochemistry, 49(12), 2313-2319.

Gan, L., Zhang, S., Zhang, Y., He, S., \& Tian, Y. (2018). Biosynthesis, characterization and antimicrobial activity of silver nanoparticles by a halotolerant $\mathrm{Ba}$ cillus endophyticus SCU-L. Preparative Biochemistry and Biotechnology, 48(7), 582-588.

Gao, L., Fan, K., \& Yan, X. (2017). Iron oxide nanozyme: A multifunctional enzyme mimetic for biomedical applications. Theranostics, 7(13), 3207-3227.

Garole, D. J., Choudhary, B. C., Paul, D., \& Borse, A. U. (2018). Sorption and recovery of platinum from simulated spent catalyst solution and refinery 
wastewater using chemically modified biomass as a novel sorbent. Environmental Science and Pollution Research, 25(11), 10911-10925.

Ghiuță, I., Cristea, D., Croitoru, C., Kost, J., Wenkert, R., Vyrides, I., Anayiotos, A., \& Munteanu, D. (2018). Characterization and antimicrobial activity of silver nanoparticles, biosynthesized using Bacillus species. Applied Surface Science, 438, 66-73.

Goutam, S. P., Saxena, G., Roy, D., Yadav, A. K., \& Bharagava, R. N. (2020) Green synthesis of nanoparticles and their applications in water and wastewater treatment. In: Saxena, G., \& Bharagava, R. N. (Eds.). Bioremediation of industrial waste for environmental safety. Springer Nature, Singapore. Pp. 349-379.

Grillone, A., Li, T., Battaglini, M., Scarpellini, A., Prato, M., Takeoka, S., \& Ciofani, G. (2017). Preparation, characterization, and preliminary in vitro testing of nanoceria-loaded liposomes. Nanomaterials, 7(9), 276.

Grzelczak, M., \& Liz-Marzán, L. M. (2014). The relevance of light in the formation of colloidal metal nanoparticles. Chemical Society Reviews, 43(7), 2089-2097.

Gupta, R., \& Padmanabhan, P. (2018). Biogenic synthesis and characterization of gold nanoparticles by a novel marine bacteria Marinobacter algicola: Progression from nanospheres to various geometrical shapes. The Journal of Microbiology, Biotechnology and Food Sciences, 8(1), 732

Halliwell, B. (2006). Reactive species and antioxidants. Redox biology is a fundamental theme of aerobic life. Plant Physiology, 141(2), 312-322.

He, S., Guo, Z., Zhang, Y., Zhang, S., Wang, J., \& Gu, N. (2007). Biosynthesis of gold nanoparticles using the bacteria Rhodopseudomonas capsulata. Materials Letters, 61(18), 3984-3987.

Honary, S., Gharaei-Fathabad, E., Paji, Z. K., \& Eslamifar, M. (2012). A novel biological synthesis of gold nanoparticle by Enterobacteriaceae family. Tropical Journal of Pharmaceutical Research, 11(6), 887-891.

Huang, Z., Zeng, Z., Chen, A., Zeng, G., Xiao, R., Xu, P., He, K., Song, Z., Hu, L., Peng, M., Huang, T., \& Chen, G. (2018). Differential behaviors of silver nanoparticles and silver ions towards cysteine: Bioremediation and toxicity to Phanerochaete chrysosporium. Chemosphere, 203, 199-208.

Hulkoti, N. I., \& Taranath, T. C. (2014). Biosynthesis of nanoparticles using microbes - a review. Colloids and Surfaces B: Biointerfaces, 121, 474-483.

Jayaseelan, C., Rahuman, A. A., Kirthi, A. V., Marimuthu, S., Santhoshkumar, T. Bagavan, A., Gaurav, K., Karthik, L., \& Rao, K. B. (2012). Novel microbial route to synthesize $\mathrm{ZnO}$ nanoparticles using Aeromonas hydrophila and their activity against pathogenic bacteria and fungi. Spectrochimica Acta Part A: Molecular and Biomolecular Spectroscopy, 90, 78-84

Jiang, Z., Zhang, S., Klausen, L. H., Song, J., Li, Q., Wang, Z., Stokke, T. B., Huang Y., Besenbacher, F., Nielsen, L. P., \& Dong, M. (2018). In vitro single-cell dissection revealing the interior structure of cable bacteria. Proceedings of the $\mathrm{Na}-$ tional Academy of Sciences, 115(34), 8517-8522.

Kalimuthu, K., Babu, R. S., Venkataraman, D., Bilal, M., \& Gurunathan, S. (2008) Biosynthesis of silver nanocrystals by Bacillus licheniformis. Colloids and Surfaces B, Biointerfaces, 65(1), 150-153.

Kalishwaralal, K., Deepak, V., Pandian, S. R. K., Kottaisamy, M., BarathManiKanth, S., Kartikeyan, B., \& Gurunathan, S. (2010). Biosynthesis of silver and gold nanoparticles using Brevibacterium casei. Colloids and Surfaces B: Biointerfaces, 77(2), 257-262.

Kang, F., Qu, X., Alvarez, P. J., \& Zhu, D. (2017). Extracellular saccharide-mediated reduction of $\mathrm{Au}^{3+}$ to gold nanoparticles: New insights for heavy metals biomineralization on microbial surfaces. Environmental Science and Technology, 51(5), 2776-2785.

Karakoti, A. S., Munusamy, P., Hostetler, K., Kodali, V., Kuchibhatla, S., Orr, G. Pounds, J. G., Teeguarden, J. G., Thrall, B. D., \& Baer, D. R. (2012). Preparation and characterization challenges to understanding environmental and biological impacts of ceria nanoparticles. Surface and Interface Analysis, Surface and Interface Analysis, 44(8), 882-889.

Katz, A., Alimova, A., Xu, M., Rudolph, E., Shah, M. K., Savage, H. E., Rosen, R. B., McCormick, S. A., \& Alfano, R. R. (2003). Bacteria size determination by light scattering. IEEE Journal of Selected Topics in Quantum Electronics, 9(2), 277-287.

Kim, J. S., Kuk, E., Yu, K. N., Kim, J. H., Park, S. J., Lee, H. J., Kim, S. H., Park, Y. K., Park, Y. H., Hwang, C-Y., Kim, Y. K., Lee, Y-S., Jeong, D. H., \& Cho, M.-H. (2007). Antimicrobial effects of silver nanoparticles. Nanomedicine: Nanotechnology, Biology and Medicine, 3(1), 95-101.

Kimber, R. L., Lewis, E. A., Parmeggiani, F., Smith, K., Bagshaw, H., Starborg, T., Smith, K., Joshi, N., Figueroa, A. I., Van der Laan, G., Cibin, G., Gianolio, D. Haigh, S. J., Pattrick, R., Tumer, N. J., \& Lloyd, J. R. (2018). Biosynthesis and characterization of copper nanoparticles using Shewanella oneidensis: Application for click chemistry. Small, 14(10), 1703145

Klaus, T., Joerger, R., Olsson, E., \& Granqvist, C. G. (1999). Silver-based crystalline nanoparticles, microbially fabricated. Proceedings of the National Academy of Sciences, 96(24), 13611-13614.

Kozik, V. V., Shcherbakov, A. B., Ivanova, O. S., Spivak, N. Y., \& Ivanov, V. K (2016). Synthesis and biomedical applications of nanodispersed cerium dioxide. Izdatelskiy Dom Tomskogo Gosudarstvennogo Universiteta, Tomsk.
Li, J., Tian, B., Li, T., Dai, S., Weng, Y., Lu, J., Xu, X., Jin, Y., Pang, R., \& Hua, Y. (2018). Biosynthesis of $\mathrm{Au}, \mathrm{Ag}$ and $\mathrm{Au}-\mathrm{Ag}$ bimetallic nanoparticles using protein extracts of Deinococcus radiodurans and evaluation of their cytotoxicity. International Journal of Nanomedicine, 13, 1411.

Li, L., Hu, Q., Zeng, J., Qi, H., \& Zhuang, G. (2011). Resistance and biosorption mechanism of silver ions by Bacillus cereus biomass. Journal of Environmental Sciences, 23(1), 108-111.

Li, M., \& Zhang, C. (2016). $\gamma$ - $\mathrm{Fe}_{2} \mathrm{O}_{3}$ nanoparticle-facilitated bisphenol A degradation by white rot fungus. Science Bulletin, 61(6), 468-472.

Li, X., Xu, H., Chen, Z. S., \& Chen, G. (2011b). Biosynthesis of nanoparticles by microorganisms and their applications. Journal of Nanomaterials, 2011, 270974

Lin, Y., Ren, J., \& Qu, X. (2014). Nano-gold as artificial enzymes: Hidden talents. Advanced Materials, 26(25), 4200-4217

Liu, B., Sun, Z., Huang, P. J. J., \& Liu, J. (2015). Hydrogen peroxide displacing DNA from nanoceria: Mechanism and detection of glucose in serum. Journal of the American Chemical Society, 137(3), 1290-1295.

Liu, W., Tian, S., Zhao, X., Xie, W., Gong, Y., \& Zhao, D. (2015a). Application of stabilized nanoparticles for in situ remediation of metal-contaminated soil and groundwater: A critical review. Current Pollution Reports, 1, 280-291.

Lok, C. N., Ho, C. M., Chen, R., He, Q. Y., Yu, W. Y., Sun, H., Tam, P. K., Chiu, J. F., \& Che, C. M. (2006). Proteomic analysis of the mode of antibacterial action of silver nanoparticles. Journal of Proteome Research, 5(4), 916-924.

Lu, L., Wang, X., Xiong, C., \& Yao, L. (2015). Recent advances in biological detection with magnetic nanoparticles as a useful tool. Science China Chemistry, 58(5), 793-809.

Lv, Q., Zhang, B., Xing, X., Zhao, Y., Cai, R., Wang, W., \& Gu, Q. (2018). Biosynthesis of copper nanoparticles using Shewanella loihica PV-4 with antibacterial activity: Novel approach and mechanisms investigation. Journal of Hazardous Materials, 347, 141-149.

Lyubchenko, Y. L., \& Shlyakhtenko, L. S. (1997). Visualization of supercoiled DNA with atomic force microscopy in situ. Proceedings of the National Academy of Sciences, 94(2), 496-501.

Manoj, D., Saravanan, R., Santhanalakshmi, J., Agarwal, S., Gupta, V. K., \& Boukherroub, R. (2018). Towards green synthesis of monodisperse Cu nanoparticles: An efficient and high sensitive electrochemical nitrite sensor. Sensors and Actuators B, Chemical, 266, 873-882.

Martins, M., Mourato, C., Sanches, S., Noronha, J. P., Crespo, M. B., \& Pereira, I. A (2017). Biogenic platinum and palladium nanoparticles as new catalysts for the removal of pharmaceutical compounds. Water Research, 108, 160-168.

Matsumura, Y., Yoshikata, K., Kunisaki, S. I., \& Tsuchido, T. (2003). Mode of bactericidal action of silver zeolite and its comparison with that of silver nitrate. Applied and Environmental Microbiology, 69(7), 4278-4281.

Mekkawy, A. I., El-Mokhtar, M. A., Nafady, N. A., Yousef, N., Hamad, M. A., El-Shanawany, S. M., Ibrahim, E. H., \& Elsabahy, M. (2017). In vitro and in vivo evaluation of biologically synthesized silver nanoparticles for topical applications: Effect of surface coating and loading into hydrogels. International Journal of Nanomedicine, 12, 759

Mesbahi-Nowrouzi, M. \& Mollania, N. (2018). Purification of selenate reductase from Alcaligenes sp. CKCr-6A with the ability to biosynthesis of selenium nanoparticle: Enzymatic behavior study in imidazolium based ionic liquids and organic solvent. Journal of Molecular Liquids, 249, 1254-1262.

Mikityuk, M. V. (2011). Nanoparticles and prospects for their application in biology and medicine. Problemy Ekolohii ta Medytsyny, 15(5-6), 41-49.

Mohanasrinivasan, V., Devi, C. S., Mehra, A., Prakash, S., Agarwal, A., Selvarajan, E., \& Naine, S. J. (2018). Biosynthesis of MgO nanoparticles using Lactobacillus sp. and its activity against human leukemia cell lines HL-60. BioNanoScience, 8(1), 249-253

Mokhtari, N., Daneshpajouh, S., Seyedbagheri, S., Atashdehghan, R., Abdi, K., Sarkar, S., Minaian, S., Shahverdi, H. R., \& Shahverdi, A. R. (2009). Biological synthesis of very small silver nanoparticles by culture supernatant of Klebsiella pneumonia: The effects of visible-light irradiation and the liquid mixing process. Materials Research Bulletin, 44(6), 1415-1421

Mu, X., Wang, J., Li, Y., Xu, F., Long, W., Ouyang, L., Liu, Y., Jing, Y., Wang J., Dai, H., Liu, Q., Sun, Y., Liu, C., \& Zhang, X.-D. (2019). Redox trimetallic nanozyme with neutral environment preference for brain injury. ACS Nano, 13(2), 1870-1884

Mueller, C. F., Laude, K., McNally, J. S., \& Harrison, D. G. (2005). Redox mechanisms in blood vessels. Arteriosclerosis, Thrombosis, and Vascular Biology, 25(2), 274-278.

Naik, R. R., Stringer, S. J., Agarwal, G., Jones, S. E., \& Stone, M. O. (2002). Biomimetic synthesis and patterning of silver nanoparticles. Nature Materials, 1(3), 169.

Naim, M. M., El-Shafei, A. A., Elewa, M. M., \& Moneer, A. A. (2016). Application of silver-, iron-, and chitosan-nanoparticles in wastewater treatment. International Conference on Desalination for the Environment: Clean Water and Energy, 73, 268-280. 
Nangia, Y., Wangoo, N., Goyal, N., Shekhawat, G., \& Suri, C. R. (2009). A novel bacterial isolate Stenotrophomonas maltophilia as living factory for synthesis of gold nanoparticles. Microbial Cell Factories, 8(1), 39.

Narayanan, K. B., \& Sakthivel, N. (2010). Biological synthesis of metal nanoparticles by microbes. Advances in Colloid and Interface Science, 156, 1-13.

Nasrollahzadeh, M., Sajadi, S. M., Issaabadi, Z., \& Sajjadi, M. (2019). Biological Sources Used in Green Nanotechnology. Interface Science and Technology, $28,81-111$.

Ovais, M., Khalil, A. T., Raza, A., Islam, N. U., Ayaz, M., Saravanan, M., Ali, M., Ahmad, I., Shahid, M., \& Shinwari, Z. K. (2018a). Multifunctional theranostic applications of biocompatible green-synthesized colloidal nanoparticles Applied Microbiology and Biotechnology, 102(10), 4393-4408.

Ovais, M., Zia, N., Ahmad, I., Khalil, A. T., Raza, A., Ayaz, M., Sadiq, A., Ullah, F., \& Shinwari, Z. K. (2018b). Phyto-therapeutic and nanomedicinal approaches to cure alzheimer's disease: Present status and future opportunities. Frontiers in Aging Neuroscience, 10, 284.

Pal, G., Rai, P., \& Pandey, A. (2019). Green synthesis of nanoparticles: A greener approach for a cleaner future. In: Shukla, A. K., \& Iravani, S. (Eds.). Green Synthesis, Characterization and Applications of Nanoparticles. Elsevier. Pp. 1-26.

Pantopoulos, K., \& Schipper, H. M. (2012). Principles of free radical biomedicine. Nova Science Publications, Hauppauge.

Parada, J., Rubilar, O., Diez, M. C., Cea, M., da Silva, A. S. A., Rodríguez-Rodríguez, C. E., \& Tortella, G. R. (2019). Combined pollution of copper nanoparticles and atrazine in soil: Effects on dissipation of the pesticide and on microbiological community profiles. Joumal of Hazardous Materials, 361, 228-236.

Patanjali, P., Singh, R., Kumar, A., \& Chaudhary, P. (2019). Nanotechnology for water treatment: A green approach. In: Shukla, A. K., \& Iravani, S. (Eds.) Green Synthesis, Characterization and Applications of Nanoparticles. Elsevier. Pp. 485-512.

Presentato, A., Piacenza, E., Anikovskiy, M., Cappelletti, M., Zannoni, D., \& Turner, R. J. (2018). Biosynthesis of selenium-nanoparticles and-nanorods as a product of selenite bioconversion by the aerobic bacterium Rhodococcus aetherivorans BCP1. New Biotechnology, 41, 1-8.

Rad, M., Taran, M., \& Alavi, M. (2018). Effect of incubation time, $\mathrm{CuSO}_{4}$ and glucose concentrations on biosynthesis of copper oxide $(\mathrm{CuO})$ nanoparticles with rectangular shape and antibacterial activity: Taguchi method approach. Nano Biomedicine and Engineering, 10(1), 25-33.

Ramezani, F., Ramezani, M., \& Talebi, S. (2010). Mechanistic aspects of biosynthesis of nanoparticles by several microbes. Nanocon, 10(12-14), 1-7.

Rauscher, H., Sokull-Klüttgen, B., \& Stamm, H. (2012) The European Commission's recommendation on the definition of nanomaterial makes an impact. Nanotoxicology, 7, 1195-1197.

Rautela, A., Rani, J., \& Das, M. D. (2019). Green synthesis of silver nanoparticles from Tectona grandis seeds extract: Characterization and mechanism of antimicrobial action on different microorganisms. Journal of Analytical Science and Technology, 10(1), 5 .

Reverberi, A. P., Vocciante, M., Lunghi, E., Pietrelli, L., \& Fabiano, B. (2017) New trends in the synthesis of nanoparticles by green methods. Chemical Engineering Transactions, 61, 667-672

San Diego, K. D., Alindayu, J. I. A., \& Baculi, R. Q. (2019). Biosynthesis of gold nanoparticles by bacteria from hyperalkaline spring and evaluation of their nhibitory activity against pyocyanin production. Journal of Microbiology, Biotechnology and Food Sciences, 2019, 781-787.

Sanjay, S. S. (2019). Safe nano is green nano. In: Shukla, A. K., \& Iravani, S. (Eds.). Green synthesis, characterization and applications of nanoparticles. Elsevier. Pp. 27-36.

Schlüter, M., Hentzel, T., Suarez, C., Koch, M., Lorenz, W. G., Böhm, L., Düring, R A., Koinig, K. A., \& Bunge, M. (2014). Synthesis of novel palladium (0) nanocatalysts by microorganisms from heavy-metal-influenced high-alpine sites for dehalogenation of polychlorinated dioxins. Chemosphere, 117, 462-470.

Seifan, M., Ebrahiminezhad, A., Ghasemi, Y., Samani, A. K., \& Berenjian, A. (2018). The role of magnetic iron oxide nanoparticles in the bacterially induced calcium carbonate precipitation. Applied Microbiology and Biotechnology, 102(8), 3595-3606.

Selvakannan, P. R., Ramanathan, R., Plowman, B. J., Sabri, Y. M., Daima, H. K., O'Mullane, A. P., Bansal, V., \& Bhargava, S. K. (2013). Probing the effect of charge transfer enhancement in off resonance mode SERS via conjugation of the probe dye between silver nanoparticles and metal substrates. Physical Chemistry Chemical Physics, 15(31), 12920-12929.

Selvakannan, P. R., Swami, A., Srisathiyanarayanan, D., Shirude, P. S., Pasricha, R., Mandale, A. B., \& Sastry, M. (2004). Synthesis of aqueous Au core-Ag shell nanoparticles using tyrosine as a $\mathrm{pH}$-dependent reducing agent and assembling phase-transferred silver nanoparticles at the air - water interface. Langmuir, 20(18), 7825-7836.

Selvarajan, E., \& Mohanasrinivasan, V. (2013). Biosynthesis and characterization of $\mathrm{ZnO}$ nanoparticles using Lactobacillus plantarum VITES07. Materials Letters, $112,180-182$
Shah, J. H., Fiaz, M., Athar, M., Ali, J., Rubab, M., Mehmood, R., Jamil, S. U. U., \& Djellabi, R. (2019). Facile synthesis of N/B-double-doped $\mathrm{Mn}_{2} \mathrm{O}_{3}$ and $\mathrm{WO}_{3}$ nanoparticles for dye degradation under visible light. Environmental Technology, 2019, 1-10.

Shakibaie, M., Amiri-Moghadam, P., Ghazanfari, M., Adeli-Sardou, M., Jafari, M., \& Forootanfar, H. (2018). Cytotoxic and antioxidant activity of the biogenic bismuth nanoparticles produced by Delftia sp. SFG. Materials Research Bulletin, 104, 155-163.

Shankar, P. D., Shobana, S., Karuppusamy, I., Pugazhendhi, A., Ramkumar, V. S., Arvindnarayan, S., \& Kumar, G. (2016). A review on the biosynthesis of metallic nanoparticles (gold and silver) using bio-components of microalgae: Formation mechanism and applications. Enzyme and Microbial Technology, 95, 28 -44.

Shankar, S., Soni, S. K., Daima, H. K., Selvakannan, P. R., Khire, J. M., Bhargava, S. K., \& Bansal, V. (2015). Charge-switchable gold nanoparticles for enhanced enzymatic thermostability. Physical Chemistry Chemical Physics, 17(33), 21517-21524

Sharma, K. D. (2017). Antifungal activity of biogenic platinum nanoparticles: An in vitro study. International Journal of Current Microbiology and Applied Sciences, 6(4), 334-340.

Shin, D. S., DiDonato, M., Barondeau, D. P., Hura, G. L., Hitomi, C., Berglund, J. A., \& Tainer, J. A. (2009). Superoxide dismutase from the eukaryotic thermophile $\mathrm{Al}$ vinella pompejana: Structures, stability, mechanism, and insights into amyotrophic lateral sclerosis. Journal of Molecular Biology, 385(5), 1534-1555.

Si, S., \& Mandal, T. K. (2007). Tryptophan-based peptides to synthesize gold and silver nanoparticles: A mechanistic and kinetic study. Chemistry - A European Journal, 13(11), 3160-3168.

Siddiqi, K. S., Husen, A., \& Rao, R. A. (2018). A review on biosynthesis of silver nanoparticles and their biocidal properties. Journal of Nanobiotechnology, 16(1), 14.

Singaravelu, G., Arockiamary, J. S., Kumar, V. G., \& Govindaraju, K. (2007). A novel extracellular synthesis of monodisperse gold nanoparticles using marine alga, Sargassum wightii Greville. Colloids and Surfaces B: Biointerfaces, 57(1), 97-101.

Singh, O. V. (Ed.). (2015). Bio-nanoparticles: Biosynthesis and sustainable biotechnological implications. John Wiley \& Sons.

Singh, P., Kim, Y. J., Zhang, D., \& Yang, D. C. (2016). Biological synthesis of nanoparticles from plants and microorganisms. Trends in Biotechnology, 34(7), 588-599.

Singh, S., Kumar, V., Romero, R., Sharma, K., \& Singh, J. (2019). Applications of nanoparticles in wastewater treatment. In: Nanobiotechnology in bioformulations. Springer, Cham. Pp. 395-418.

Singh, V. K., \& Singh, A. K. (2019). Role of microbially synthesized nanoparticles in sustainable agriculture and environmental management. In: Role of plant growth promoting microorganisms in sustainable agriculture and nanotechnology. Woodhead Publishing. Pp. 55-73.

Sintubin, L., De Windt, W., Dick, J., Mast, J., van der Ha, D., Verstraete, W., \& Boon, N. (2009). Lactic acid bacteria as reducing and capping agent for the fast and efficient production of silver nanoparticles. Applied Microbiology and Biotechnology, 84(4), 741-749.

Stoller, M., Di Palma, L., Vuppala, S., Verdone, N., \& Vilardi, G. (2018). Proces intensification techniques for the production of nano-and submicronic particles for food and medical applications. Current Pharmaceutical Design, 24(21), 2329-2338.

Taran, M., Rad, M., \& Alavi, M. (2017). Antibacterial activity of copper oxide (CuO) nanoparticles biosynthesized by Bacillus sp. FU4: Optimization of experiment design. Pharmaceutical Sciences, 23(3), 198-206.

Temerk, Y., \& Ibrahim, H. (2016). A new sensor based on In doped $\mathrm{CeO}_{2}$ nanoparticles modified glassy carbon paste electrode for sensitive determination of uric acid in biological fluids. Sensors and Actuators B: Chemical, 224, 868-877.

Thakkar, K. N., Mhatre, S. S., \& Parikh, R. Y. (2010). Biological synthesis of metallic nanoparticles. Nanomedicine: Nanotechnology, Biology and Medicine, 6(2), 257-262

Titus, D., Samuel, E. J. J., \& Roopan, S. M. (2019). Nanoparticle characterization techniques. In: Shukla, A. K., \& Iravani, S. (Eds.). Green synthesis, characterization and applications of nanoparticles. Elsevier. Pp. 303-319.

Tomer, A. K., Rahi, T., Neelam, D. K., \& Dadheech, P. K. (2019). Cyanobacterial extract-mediated synthesis of silver nanoparticles and their application in ammonia sensing. International Microbiology, 22(1), 49-58.

Touyz, R. M. (2005). Molecular and cellular mechanisms in vascular injury in hypertension: Role of angiotensin II - editorial review. Current Opinion in Nephrology and Hypertension, 14(2), 125-131.

Tsekhmistrenko, O. S., Tsekhmistrenko, S. I., Bityutskyy, V. S., Melnichenko, O. M., Oleshko, O. A. (2018a). Biomimetic and antioxidant activity of nanocrystalline cerium dioxide. World of Medicine and Biology, 63, 196-201.

Tsekhmistrenko, S. I., Bityutskyy, V. S., Tsekhmistrenko, O. S., Polishchuk, V. M. Polishchuk, S. A., Ponomarenko, N. V., Melnychenko, Y. O., \& Spivak, M. Y. (2018). Enzyme-like activity of nanomaterials. Regulatory Mechanisms in Biosystems, 9(3), 469-476. 
Tsekhmistrenko, O. S., Bityutskyy, V. S., Tsekhmistrenko, S. I., Melnichenko, O. M., Tymoshok, N. O., \& Spivak, M. Y. (2019). Use of nanoparticles of metals and non-metals in poultry farming. Animal Husbandry Products Production and Processing, 2, 113-130.

Tymoshok, N. O., Kharchuk, M. S., Kaplunenko, V. G., Bityutskyy, V. S., Tsekhmistrenko, S. I., Tsekhmistrenko, O. S., Spivak, M. Y., \& Melnichenko, O. M. (2019). Evaluation of effects of selenium nanoparticles on Bacillus subtilis. Regulatory Mechanisms in Biosystems, 10(4), 544-552.

Vaidyanathan, R., Gopalram, S., Kalishwaralal, K., Deepak, V., Pandian, S. R. K., \& Gurunathan, S. (2010). Enhanced silver nanoparticle synthesis by optimization of nitrate reductase activity. Colloids and Surfaces B: Biointerfaces, 75(1), 335-341.

Valko, M., Rhodes, C., Moncol, J., Izakovic, M. M., \& Mazur, M. (2006). Free radicals, metals and antioxidants in oxidative stress-induced cancer. Chemico-Biological Interactions, 160(1), 1-40.

Venil, C. K., Sathishkumar, P., Malathi, M., Usha, R., Jayakumar, R., Yusoff, A. R. M., \& Ahmad, W. A. (2016). Synthesis of flexirubin-mediated silver nanoparticles using Chryseobacterium artocarpi CECT 8497 and investigation of its anticancer activity. Materials Science and Engineering: C, 59, 228-234

Wadhwani, S. A., Shedbalkar, U. U., Singh, R., \& Chopade, B. A. (2018). Biosynthesis of gold and selenium nanoparticles by purified protein from Acinetobacter sp. SW 30. Enzyme and Microbial Technology, 111, 81-86.

Walkey, D. G. (2018). Virus diseases. Onions and allied crops. Volume 2. Agronomy Biotic Interactions. CRC Press, Taylor \& Francis Group.

Walser, T., Limbach, L. K., Brogioli, R., Erismann, E., Flamigni, L., Hattendorf, B., Juchli, M., Krumeich, F., Ludwig, C., Prikopsky, K., Rossier, M., Saner, D., Sigg, A., Hellweg, S., Günther, D., \& Stark, W. J. (2012). Persistence of engineered nanoparticles in a municipal solid-waste incineration plant. Nature Nanotechnology, 7(8), 520.

Wang, L., Ali, J., Zhang, C., Mailhot, G., \& Pan, G. (2017). Simultaneously enhanced photocatalytic and antibacterial activities of $\mathrm{TiO}_{2} / \mathrm{Ag}$ composite nanofibers for wastewater purification. Journal of Environmental Chemical Engineering, 2017, 102104.

Wang, L., Miao, X., Ali, J., Lyu, T., \& Pan, G. (2018a). Quantification of oxygen nanobubbles in particulate matters and potential applications in remediation of anaerobic environment. ACS Omega, 3(9), 10624-10630.

Wang, W., Zhang, B., Liu, Q., Du, P., Liu, W., \& He, Z. (2018b). Biosynthesis of palladium nanoparticles using Shewanella loihica PV-4 for excellent catalytic reduction of chromium(VI). Environmental Science: Nano, 5(3), 730-739.

Wang, X., Zhang, D., Pan, X., Lee, D. J., Al-Misned, F. A., Mortuza, M. G., \& Gadd, G. M. (2017a). Aerobic and anaerobic biosynthesis of nano-selenium for remediation of mercury contaminated soil. Chemosphere, 170, 266-273.

Wang, Z., Li, Q., Chen, Y., Cui, B., Li, Y., Besenbacher, F., \& Dong, M. (2018c) The ambipolar transport behavior of $\mathrm{WSe}_{2}$ transistors and its analogue circuits. NPG Asia Materials, 10(8), 703.

Wei, H., \& Wang, E. (2013). Nanomaterials with enzyme-like characteristics (nanozymes): Next-generation artificial enzymes. Chemical Society Reviews, 42(14), 6060-6093.
Wu, H., Yin, J. J., Wamer, W. G., Zeng, M., \& Lo, Y. M. (2014). Reactive oxygen species-related activities of nano-iron metal and nano-iron oxides. Journal of Food and Drug Analysis, 22(1), 86-94.

Wu, R., Tian, X., Xiao, Y., Ulstrup, J., Christensen, H. E. M., Zhao, F., \& Zhang, J. (2018). Selective electrocatalysis of biofuel molecular oxidation using palladium nanoparticles generated on Shewanella oneidensis MR-1. Journal of Materials Chemistry A, 6(23), 10655-10662.

Wu, W., Huang, H., Ling, Z., Yu, Z., Jiang, Y., Liu, P., \& Li, X. (2016). Genome sequencing reveals mechanisms for heavy metal resistance and polycyclic aromatic hydrocarbon degradation in Delftia lacustris strain LZ-C. Ecotoxicology, 25(1), 234-247.

Xia, X., Wu, S., Li, N., Wang, D., Zheng, S., \& Wang, G. (2018). Novel bacterial selenite reductase $\mathrm{CsrF}$ responsible for Se (IV) and $\mathrm{Cr}$ (VI) reduction that produces nanoparticles in Alishewanella sp. WH16-1. Journal of Hazardous Materials, 342, 499-509.

Yadi, M., Mostafavi, E., Saleh, B., Davaran, S., Aliyeva, I., Khalilov, R., Nikzamir, N., Akbarzadeh, A., Panahi, Y., \& Milani, M. (2018). Current developments in green synthesis of metallic nanoparticles using plant extracts: A review. Artificial Cells, Nanomedicine, and Biotechnology, 46(3), 336-343.

Yates, M. D., Cusick, R. D., \& Logan, B. E. (2013). Extracellular palladium nanoparticle production using Geobacter sulfurreducens. Acs Sustainable Chemistry and Engineering, 1(9), 1165-1171.

Yin, Y., Yang, X., Hu, L., Tan, Z., Zhao, L., Zhang, Z., Liu, J., \& Jiang, G. (2016) Superoxide-mediated extracellular biosynthesis of silver nanoparticles by the fungus Fusarium oxysporum. Environmental Science and Technology Letters, 3(4), 160-165.

Yurtluk, T., Akçay, F. A., \& Avci, A. (2018). Biosynthesis of silver nanoparticles using novel Bacillus sp. SBT8. Preparative Biochemistry and Biotechnology, 48(2), 151-159.

Zakaria, H. M., Shah, A., Konieczny, M., Hoffmann, J. A., Nijdam, A. J., \& Reeves, M. E. (2013). Small molecule-and amino acid-induced aggregation of gold nanoparticles. Langmuir, 29(25), 7661-7673.

Zhang, H., \& Hu, X. (2017). Rapid production of Pd nanoparticle by a marine electrochemically active bacterium Shewanella sp. CNZ-1 and its catalytic performance on 4-nitrophenol reduction. RSC Advances, 7(65), 41182-41189.

Zhang, H., \& Hu, X. (2018). Biosynthesis of Pd and Au as nanoparticles by a marine bacterium Bacillus sp. GP and their enhanced catalytic performance using metal oxides for 4-nitrophenol reduction. Enzyme and Microbial Technology, 113, 59-66.

Zhang, Y., Qiang, L., Yuan, Y., Wu, W., Sun, B., \& Zhu, L. (2018). Impacts of titanium dioxide nanoparticles on transformation of silver nanoparticles in aquatic environments. Environmental Science: Nano, 5(5), 1191-1199.

Zhu, Y., Ren, B., Li, H., Lin, Z., Bañuelos, G., Li, L., Zhao, G., \& Guo, Y. (2018). Biosynthesis of selenium nanoparticles and effects of selenite, selenate, and selenomethionine on cell growth and morphology in Rahnella aquatilis HX2. Applied Microbiology and Biotechnology, 2(14), 6191-6205. 